\title{
Asian Americans' Perception of Intergroup Commonality with Blacks and Latinos: The Roles of Group Consciousness, Ethnic Identity, and Intergroup Contact
}

\author{
Saemyi Park
}

Citation: Park, Saemyi. 2021. Asian Americans' Perception of Intergroup Commonality with Blacks and Latinos: The Roles of Group Consciousness, Ethnic Identity, and Intergroup Contact. Social Sciences 10: 441. https://doi.org/10.3390/ socsci10110441

Academic Editor: Nigel Parton

Received: 13 September 2021 Accepted: 15 November 2021 Published: 19 November 2021

Publisher's Note: MDPI stays neutral with regard to jurisdictional claims in published maps and institutional affiliations.

Copyright: (C) 2021 by the author. Licensee MDPI, Basel, Switzerland. This article is an open access article distributed under the terms and conditions of the Creative Commons Attribution (CC BY) license (https:/ / creativecommons.org/licenses/by/ $4.0 /)$.
Department of Political Science, University of Wisconsin-Stevens Point, Stevens Point, WI 54481, USA; spark@uwsp.edu

\begin{abstract}
This study explores the factors that influence Asian Americans' perception of interracial commonality with Blacks and Latinos. Using the 2018 Civic Engagement and Political Participation of Asian Americans Survey, this research tests a model of competing theoretical explanations for Asian Americans' intergroup commonality: group consciousness, group identity, views of discrimination, and intergroup contact. Results from ordered logistic regression analyses suggest that group consciousness, ethnic identity, and intergroup contact via friendship are robust predictors of Asian Americans' feelings of closeness to Blacks and Latinos. However, Asian Americans' perceptions of discrimination are unlikely to result in higher levels of the perceived commonality with outgroups. This study provides a valuable addition to the existing literature on interminority relations by identifying opportunities for Asian Americans to join cross-racial alliances. The conclusion of the article points to the important role that community-based organizations can play in bringing specific Asian American ethnic groups into such coalitions and promoting direct interactions between Asian Americans and other racial groups.
\end{abstract}

Keywords: Asian Americans; interracial commonality; interracial attitudes; cross-racial coalition; group consciousness; group identity; intergroup contact; views of discrimination

\section{Introduction}

Asian Americans have been the fastest-growing racial group in the United States since 2010 (Pew Research Center 2013) and are projected to grow 101\%, from 18.31 million in 2016 to 36.81 million in 2060, followed by Hispanics, whose population will also nearly double within the next four decades (Vespa et al. 2020). This demographic shift is largely driven by immigrants from Latin America and Asia, with the largest sending region of migrants since 2010 being Asia. While Blacks and people who are classified as having two or more races are also projected to grow by 2060 (41\% and 198\%, respectively), the only group projected to decline is the non-Hispanic White population (Vespa et al. 2020). In 2045, non-White racial minorities will comprise the half of the total population, and the United States will continue to be a more diverse nation, racially and ethnically, afterward (Frey 2018). The changing racial makeup of the United States in recent decades offers opportunities for racial minority groups to build "strength in numbers" through cross-racial coalitions (Nicholson et al. 2020).

In addition, the social movement in the last few years against police brutality in Black communities, as exemplified by Black Lives Matter (BLM), has demonstrated the potential to advance interracial solidarity because of the movement's expanded commitment to working on social justice for all minority groups (Bonilla and Tillery 2020; Yellow Horse et al. 2021; Huang 2021; Merseth 2018). Seemingly, the BLM movement has garnered support from Latinos who acknowledge systematic racism and share the goal of criminal justice reform (Corral 2020). Likewise, a few ethnographic studies have recorded a number of protests in New York and Minnesota where many Asian Americans attended in solidarity 
with Black Lives Matter (Liu 2018; Vang and Myers 2021). Indeed, the widespread use of xenophobic rhetoric toward racial and religious minorities during the Trump presidency and the rise of anti-Asian hate crimes during the COVID-19 pandemic have increased such prospects for minority coalition-building. As this predominantly immigrant group is often the victim of racial discrimination and racist nativism, Asian Americans would also want the type of social change emphasized by BLM activists (Gover et al. 2020; Hackman 2020; Yellow Horse et al. 2021; Lee et al. 2020; Tessler et al. 2020).

Indeed, the growing body of literature on Latino politics has explored opportunities for coalition-building between Blacks and Latinos. As perceptions of commonality are central to the formation of multiracial political coalitions (Wallsten and Nteta 2017), scholars discover that factors such as intragroup-linked fate, pan-ethnic identity or superordinary community identity, experiences or awareness of discrimination, acculturation, and environmental contexts are important predictors for Black-Brown attitudes (Corral 2020; Gomez-Aguinaga et al. 2021; Israel-Trummel and Schachter 2019; Jones-Correa et al. 2016; Kaufmann 2003; Martinez-Ebers et al. 2021; McClain et al. 2009; Sanchez 2008; Wilkinson 2014). When it comes to Asian Americans' intergroup commonality, there is a small amount of meaningful qualitative work that examines possibilities and challenges in Asian American collaborations with other groups of color in California (Hope 2019; Johnson 2004; Kim and Lee 2001; Okamoto and Gast 2013; Ramakrishnan 2014). Recently, more scholarly efforts have been made to examine what contributes to shaping the interracial attitudes of Asian Americans toward Blacks (Arora et al. 2021; Yellow Horse et al. 2021; Merseth 2018; Nicholson et al. 2020) and Latinos (Huang 2021; Lu 2020a). Yet this topic of research is relatively understudied as well, as quantitative research that tests all competing theoretical explanations in a model is limited. This is odd, given the heightened prospects for bringing Asian Americans into "rainbow coalitions" for more sustainable social change during the BLM era.

Our goal in this paper is to understand how Asian Americans perceive commonality with Blacks and Latinos, as well as to ascertain what factors determine their interracial attitudes by focusing on group consciousness, group identity, views of discrimination, and intergroup contact. While previous research on Latino intergroup relations shows that these variables can explain the strength of Black-Brown solidarity, it is not clear whether they also determine Asian American outgroup attitudes. In fact, a few existing studies on Asian Americans' perceptions of commonality toward other racial groups present inconclusive results. There are various reasons why this group's feelings of closeness to outgroups would operate differently. For instance, Asian Americans show lower rates of linked fate (Junn and Masuoka 2008), demonstrate strong divisions in terms of religion, language, and immigration patterns (Aoki and Takeda 2008; Wong et al. 2011), and lack the collective history and memory of discrimination (Huang 2021, p. 181) compared with other racial and ethnic minority groups. Thus, it is critical to fully examine the competing theories in order to provide a comprehensive analysis of Asian American interracial attitudes. While previous studies have focused on the binary relations of Asian Americans with either Blacks or Latinos, we look at this group's perceived commonality with both racial groups, which enriches scholarly discussion on cross-racial solidarity.

The remainder of this paper is organized into three sections. First, we review the existing studies to extract the possible explanations for intergroup commonality and crossracial solidarity. We then present ordered logistic regression analyses from the 2018 Civic Engagement and Political Participation of Asian Americans Survey (CEPPAAS), which show that group consciousness, ethnic identity, and intergroup contact via friendship are significant determinants of Asian American respondents' feelings of interracial commonality. We conclude by discussing the implications of these findings to highlight the roles of community-based organizations (CBOs) for inter-minority alliance, as CBOs can bring Asian Americans with a strong ethnic identity into a variety of programs where direct interactions occur with outgroups. This research contributes to broadening our understanding of multiracial coalitions. 


\section{Existing Literature and Theoretical Framework}

\subsection{Group Consciousness}

Group consciousness is a dominant concept in research on the political behavior and attitudes of racial and ethnic minorities. While it is conceptualized in numerous ways, most researchers use the definition of group consciousness from the work of McClain and others, which is defined as a form of "in-group identification that is politicized by a set of ideological beliefs about one's group's social standing, as well a view that collective action is the best means by which the group can improve its status and realize its interests" (McClain et al. 2009, p. 476). It is important to note that scholars have operationalized this concept in various manners, but the measurement of group consciousness contains common elements, such as "having a sense of belonging to the group", "an expressed satisfaction or dissatisfaction with the group's current status, power, or material resource in relation to those of an out-group", and "the belief that a group's social status is attributable to individual failings or to structural inequalities" (Herrick and Mendez 2019).

In explaining Latino commonality with Blacks, Latinos' group consciousness turns out to be a significant predictor for Latino/Black commonality. Latinos who have a greater sense of intragroup commonality (Sanchez 2008; Wilkinson 2014) and who show a higher level of pan-Latino affinity or internal closeness (Kaufmann 2003) are more likely to report political commonality with Blacks. A concept related to group consciousness is linked fate, which is conceptualized from the "black utility heuristic" in Dawson (1994)'s influential work. Given the occurrence of racial conflict throughout American history, Black Americans' individual life chances are largely determined by their race and the social standing of the group has to be used as a proxy for the wellbeing of the individual, which makes them a politically cohesive group, regardless of class divisions (Masuoka 2006; McClain et al. 2009, p. 477). Scholars of Latino politics have borrowed this idea to see whether linked fate has similar effects on Latinos, who have also faced many types of discrimination in the United States. They also find that Latinos who see their fate as being tied to that of other Latinos are more likely to participate in non-political activities (Sanchez 2006; Stokes 2003) and feel that they have the most in common with Blacks (McClain et al. 2009; Gomez-Aguinaga et al. 2021; Jones-Correa et al. 2016; though see Israel-Trummel and Schachter 2019).

Likewise, a handful of studies focuses on examining the role of group consciousness and linked fate within the Asian American population (Junn and Masuoka 2008; Le et al. 2020; Lien et al. 2004; Masuoka 2006; Phoenix and Arora 2018). Yet the effects of these variables may be less clear for Asian Americans. The primary focus of research on Asian Americans has been concentrated on the relationship between political participation and group consciousness/linked fate. Previous research notes that Asian Americans tend to have weaker linked fate than Latinos and are more likely to identify with an ethnic group based on their national origin than having pan-Asian group consciousness (Masuoka 2006; Wong et al. 2011). Wong et al. (2005) found that group consciousness has little effect on voting but does affect other types of political activities. However, the impact is conditional on the racial context in which Asian Americans live (Rim 2009). There is also a cautionary interpretation that Asian American group consciousness can be developed through social interaction or life experiences of discrimination (Masuoka 2006) and by threats such as the anti-Asian rhetoric that transpired during the Trump presidency (Le et al. 2020). When it comes to Asian American interracial attitudes, a few recent studies demonstrate that group consciousness and linked fate are positively associated with feelings of closeness with Blacks (Nicholson et al. 2020) and support for BLM (Merseth 2018). While a few studies exist that examine the role of group consciousness/linked fate on Asian American attitudes toward outgroups, it is limited to this group's perception of commonality with Blacks. How Asian American attitudes toward Latinos are related to group consciousness and linked fate has not been fully studied. Thus, this paper aims at discovering if and how these variables work for Asian Americans' feelings of closeness to both Blacks and Latinos. 


\subsection{Group Identity}

Group identification refers to an individual's awareness of belonging to a certain group and having a psychological attachment to that group based on the perception of shared beliefs, feelings, interests, and ideas with other in-group members (McClain et al. 2009, p. 474). As the concept of race has been so important and consequential in establishing and maintaining systems of power in the United States, scholars studying group identity have largely focused on racial identity and its impact on the political behaviors and attitudes of individuals (Allen et al. 1989; Broman et al. 1988; Masuoka 2008; Min 2014; Stokes-Brown 2006; Wong et al. 2011). Beyond the simple feelings of in-group closeness, many researchers conceptualize racial identity as a multidimensional construct consisting in part of the physical, psychological, sociopolitical, and cultural elements of life for racial groups in the United States (McClain et al. 2009, p. 474). In particular, major demographic changes in the United States driven by the immigration of non-White populations have led academics to measure racial identity that can grasp the racial, linguistic, and immigrant status diversity among Latinos and Asian Americans (Corral 2020).

Previous studies have found Latino racial identity to be politically significant (StokesBrown 2009), but the findings on its relationship with feelings of closeness to outgroups are inconclusive. In comparison to Latinos who identify racially as White, Latinos who ascribe to the Hispanic/Latino label are more likely to report perceived commonality with Blacks (Gomez-Aguinaga et al. 2021; Wilkinson 2015). Although they are less likely to be aware of the BLM movement, Latinos who identify racially as Hispanics or Latinos are more likely to support and believe that the BLM movement can effectively meet its goals (Corral 2020). However, other scholars find that Latinos who identify more as Americans also perceive higher levels of commonality with the Black population of the United States (Gomez-Aguinaga et al. 2021) and that Latinos who self-identify as Black or Latino are only slightly more likely to feel close to Blacks, as are Latinos who identify as White (Kaufmann 2003). In their study of interracial coalitions in Los Angeles, Martinez-Ebers and her colleagues (2021) claim that emphasizing a superordinate "community" identity increases feelings of closeness in the attitudes of Whites and Latinos toward one another as well as toward Blacks and Asians, while racial identity does not appear to influence cross-racial attitudes among Whites and Latinos.

Along with Latinos, the Asian American population is also very diverse in terms of national origin, language, and immigration history, and there is no one ethnicity that predominates in this group (Aoki and Takeda 2008; Lien et al. 2004; Wong et al. 2011). Thus, scholars have challenged the formation of a monolithic Asian American bloc and highlighted the importance of recognizing intragroup heterogeneity in studying Asian Americans (Arora et al. 2021; Drouhot and Garip 2021; Huang 2021; Wong et al. 2011). Previous research notes that Asian Americans are more likely to identify with an ethnic group based on their national origin than pan-ethnic racial identity (Junn and Masuoka 2008; Lien et al. 2003; Masuoka 2006). However, a recent study by Fan Lu (2020b) discovered that both race and ethnicity can be salient to the same Asian American individual. When it comes to their roles in Asian American interracial attitudes, the correlation between racial group identity and intergroup commonality is not conclusive. Some scholars have found that neither racial identity nor ethnic identity was found to play a significant role in shaping support for BLM (Arora and Stout 2019; Merseth 2018) or indifference to it (Yellow Horse et al. 2021). Other researchers have discovered that Asian American pan-ethnic identity is related to intergroup commonality via the process whereby Asian Americans define their racial identity as an expression of a racialized otherness that makes them feel closer to Blacks and Latinos in the social-racial hierarchy as a result (Cho 2020; Zheng 2019). Thus, our goal in this research is to find what form of identification among Asian Americans-a racial identity or an ethnic identity—will result in their being more closely aligned with Blacks and Latinos. 


\subsection{Experiences or Perceptions of Discrimination}

It is well documented that Black Americans' historical experiences of discrimination are critical to influencing group identity and political participation (Austin et al. 2012; Dawson 1994). Like Blacks in the United States, many Latinos experience severe social and economic discrimination and often see "their opportunities for upward mobility and political inclusion thwarted by a larger culture that discriminates against them and others like them" (Kaufmann 2003, p. 202). Thus, scholars have examined the role of experiences and perceptions of racial discrimination in intergroup commonality, because these experiences become the basis for the feeling of closeness between minority groups (Corral 2020; Sanchez 2008). The underlying assumption is that individuals who believe that their ingroup is somehow treated differently and negatively by the majority group not only develop favorable attitudes toward outgroups when they think of themselves as part of the "disadvantaged racial minority" group (Craig and Richeson 2012; Kaufmann 2003), but also see some value in trying to change the situation through collective action against unequal and unfair treatment of the ingroup (Herrick and Mendez 2019, p. 1579; McClain et al. 2009).

When it comes to Latino-Black relations, however, there are inconclusive findings about the relationship between discrimination experiences and intergroup commonality. On the one hand, recurring experiences of discrimination have a significant impact in shaping Latinos' perception of commonality with Blacks because they realize that racial conflict in the United States is an institutionalized problem (Corral 2020; Craig and Richeson 2012; Sanchez 2008). On the other hand, Latinos' feelings of closeness to Blacks may not be correlated with the experience of discrimination (Kaufmann 2003). For instance, experimental work found that Latinos who experienced educational discrimination and housing disadvantage do not necessarily report a high level of commonality with Blacks (Israel-Trummel and Schachter 2019). It is also important to note that the same group of scholars discovered that the role of discrimination experiences in Latinos' linked fate has been changed. As reviewed in the previous section, linked fate is believed to be associated with intergroup commonality. While no significant relationship between the two was found in their analysis of the 2006 Latino National Survey (Sanchez and Masuoka 2010), Sanchez and Masuoka found that both the perception of ingroup discrimination and personal experiences of discrimination predict linked fate for Latino Americans, based on an examination of the 2016 Collaborative Multiracial Post-Election Survey (Sanchez et al. 2019). These contrasting findings between the two surveys validate the importance of testing the explanatory power of discrimination experiences on interracial attitudes.

Empirical findings from the scant but growing literature on Asian American interracial attitudes are also inconsistent regarding the impact of discrimination experiences. There is developing speculation that discrimination is an important variable explaining Asian American interracial relations. The recent qualitative studies from Jeanelle Hope (2019) and May Lin (2020) find that California-based Asian American community activists are able to build Afro-Asian solidarity by emphasizing shared struggles from racializing local politics and by reframing personal discrimination experiences to the critique of racialized class inequalities in both communities. In addition, personal experiences of discrimination and beliefs about discrimination (whether respondents see it as a social problem) are known to be significant predictors for linked fate ( $\mathrm{Lu}$ and Jones 2019) and pan-ethnic group consciousness (Masuoka 2006) among Asian Americans. By contrast, a few studies provide the null finding that experiences of discrimination do not predict Asian American feelings of closeness with Blacks (Nicholson et al. 2020) or their support for BLM (Merseth 2018). For Asian Americans, experiences of discrimination are also only weakly associated with the perceived commonality with Latinos (Lu 2020a; Wong et al. 2011). Several researchers suggest that understanding the link between discrimination and Asian Americans' feelings of closeness to outgroups requires attention to the type and context of discrimination, such as interpersonal and job-related discrimination experiences (Huang 2021) or personal and residential discrimination experiences (Lu 2020a). Therefore, our goal in this paper 
is to understand the role discrimination plays in inter-minority attitudes among Asian Americans.

\subsection{Intergroup Contact}

Existing approaches to intergroup attitudes and interactions between Blacks and Latinos are framed mainly in the narrative of political and economic conflicts and competition. The group competition theory posits that members of disadvantaged racial and ethnic groups are likely to perceive each other as economic and political competitors (McClain et al. 2009; Wilkinson 2014). Intergroup competition between Blacks and Latinos occurs due to their shared social disadvantage of being located at the bottom of the social structure to "fight for crumbs" or "a zero-sum game" (Bobo and Hutchings 1996; Morris and Gimpel 2007). As a result, Latinos living in a high-threat environment with high unemployment and poverty rates (Wilkinson 2014) and, in Southern states with large outgroups (GomezAguinaga et al. 2021), have higher perceptions of competition with Blacks. Grounded in the group competition theory, researchers have also explored the role of outgroup interaction on Black-Brown interracial attitudes beyond minority population density. The intergroup contact theory claims that positive intergroup contact fosters positive views of outgroups and can motivate more collaborative behavior (McClain et al. 2009; Oliver and Wong 2003; Wilkinson 2014, 2015). Studies have found that negative stereotypes and perceptions of competition between Blacks and Latinos decrease as their communities become more diverse (Gaertner et al. 1994; Oliver and Wong 2003) as well as when they have friendships with people of different racial and ethnic backgrounds (Ellison and Powers 1994; Sigelman and Welch 1993; Wilkinson 2014, 2015). However, there are a few exceptional findings that run counter to theories of group competition and intergroup contact. For instance, GomezAguinaga and her colleagues (2021) found that Latinos generally perceive co-ethnics as a greater source of competition than Blacks and having an interracial friendship in a racially divided environment is not correlated with a lower level of group competition between the two groups.

Explanations for interracial conflicts and intergroup contact expand to find the association between resource competition and racial stereotypes/prejudice. The 1992 Los Angeles unrest attracted unusually high media and public attention because of the multiracial nature of involvement by Black, Korean, Latino, and White Americans and its massive scale of violence (Kim 2000, 2004). It inspired scholars to examine reciprocal prejudices among racial and ethnic groups (Bobo et al. 1994; Jennings 1994; Min 1996). In particular, several studies found anti-Black prejudices among Korean merchants in the Black community (Jo 1992; Koch and Schockman 1994; Weitzer 1997) as well as within the Asian American population (Lee 2000; Tokeshi 2021). When it comes to the role of stereotypes and prejudice on interracial commonality, several studies suggest that perceptions of interracial competition are associated with hostile and stereotypical images of outgroup members, thus resulting in a low level of political commonality with other groups (Corral 2020; McClain et al. 2009). Similarly, the previous literature on Asian American intergroup commonality shows that respondents who do not view outgroup members with a stereotypical lens, and who also acknowledge the existence of anti-Black racism in the United States, are more likely to report feelings of closeness to Blacks and Latinos (Johnson 2004; Merseth 2018; Hope 2019; Yellow Horse et al. 2021). Although these studies have not tested the roles of group competition and social contact in the model, they suggest that friendships and increasing intergroup contact in neighborhoods may reduce Asian Americans' stereotypical perceptions of outgroup members. Our prediction is based on the notion that Asian Americans hold a unique social position in the United States racial hierarchy (Kim 1999). It is commonly acknowledged that Asian Americans are stereotypically smart, affluent, hardworking, and politically silent and nonviolent, thus being "a model minority" (Kwon and Au 2010; Sakamoto et al. 2012). Indeed, the figures for Asian American socioeconomic status show that this group is more likely to earn a bachelor's degree and have a higher median household income than Blacks and Latinos (Budiman and Ruiz 2021). However, 
these stereotypes operate to minimize the perils Asian Americans experience, such as persistent discrimination (Nicholson et al. 2020, p. 109). Kim (1999) argues that Asian Americans are racially triangulated within the United States racial hierarchy where Whites place them as "superior" to Blacks but simultaneously ostracize them as "foreign", and this process of "racial triangulation" perpetuates anti-Black racism among Asian Americans and pits Asian Americans against other racial minority groups. Thus, the theoretical prediction is that Asian Americans' unfavorable attitudes toward outgroups are not caused by intergroup competition driven by economic interests but have resulted from the process of racial triangulation. Then, anti-Black and anti-Latino racism among Asian Americans could be reduced by increasing social contact between Asian Americans and other groups. Therefore, this paper seeks to examine if Asian Americans who reside in a racially diverse community and are surrounded by non-White outgroup members will perceive more commonality with Blacks and Latinos.

As findings from empirical tests of competing hypotheses in the existing literature on intergroup commonality have been mixed, we include four sets of factors in the modelgroup consciousness, group identity, beliefs about discrimination, and intergroup contactto identify the most significant predictor for Asian Americans' perception of intergroup commonality with Blacks and Latinos.

\section{Data and Methods}

\subsection{Data}

This study uses data from the 2018 Civic Engagement and Political Participation of Asian Americans Survey (CEPPAAS). Data were collected using online recruitment panels provided by the Qualtrics survey software tool from 12 March 2018, to 2 April 2018. Qualtrics recruited Asian American participants for the current study from a population of online panel members who matched the request criteria. A total of 735 respondents have completed the survey, which was administered in English, and been compensated through the Qualtrics credit system. To check generalizability and external validity, we compare CEPPAAS to the national probability samples of Asians used in other studies in terms of respondent characteristics. Table 1 displays the overall comparability between the CEPPAAS sample and the Asian American population in Pew Research Center's Asian American Survey (AAS) of 2013 and U.S. Census Bureau's American Community Survey (ACS) of 2015 (U.S. Census Bureau 2015). For instance, ethnic makeup in our data is similar to that in the ACS and AAS. In addition, other demographic characteristics such as gender, age, generation, education, and income are comparable in the three surveys. We can also confirm that the distribution of respondents across the regions in the CEPPAAS sample is similar to the population share of Asian Americans in the states reported in the ACS.

There are several advantages to using CEPPAAS for the examination of Asian American interracial attitudes. First, our data offer the most up-to-date information about Asian Americans. Although the literature studying Asian Americans in social science is burgeoning (Kuo et al. 2016; Lu 2020b; Nicholson et al. 2020; Phillips and Lee 2018; Samson 2015; Wong et al. 2011; Zheng 2019), it relies mostly on the 2008 National Asian American Survey (Ramakrishnan et al. 2008), and only a few recent studies on Asian American intergroup attitudes use the 2016 Collaborative Multiracial Post-Election Survey (Yellow Horse et al. 2021; Merseth 2018). Since the Obama and Trump presidencies, political contexts where racial and ethnic issues are discussed have changed significantly. Thus, it is an important task to understand if and how Asian Americans' attitudes toward other racial groups have also changed along with this shifting political background, and CEPPAAS can offer this updated information. Another merit of using these data turns on its rich array of questions covering topics of interest to this study, such as group consciousness, racial and ethnic identities, views of discrimination, contextual factors, and acculturation. CEPPAAS allows the authors to examine all four key independent variables and use two conceptualization measures for each of these multi-dimensional factors. 
Table 1. Comparison of sample characteristics between CEPPAAS and the existing data. The Asian American survey from Pew Research Center was conducted in 2012, and the updated edition of survey reports was released in 2013. Differences in coding exist for age, generation, and education in three surveys. The information about family income is not available from Pew AAS.

\begin{tabular}{|c|c|c|c|c|}
\hline Characteristics & & $\begin{array}{l}\text { Study Sample } \\
\text { (CEPPAAS 2018) }\end{array}$ & ACS (2015) & PEW AAS (2013) \\
\hline \multirow[t]{7}{*}{ National Origin } & Chinese & $26.53 \%$ & $23.00 \%$ & $20.73 \%$ \\
\hline & Asian Indian & $17.69 \%$ & $19.00 \%$ & $16.51 \%$ \\
\hline & Filipino & $17.14 \%$ & $18.00 \%$ & $14.35 \%$ \\
\hline & Japanese & $12.65 \%$ & $7.00 \%$ & $14.66 \%$ \\
\hline & Korean & $8.44 \%$ & $9.00 \%$ & $14.35 \%$ \\
\hline & Vietnamese & $7.48 \%$ & $9.00 \%$ & $14.35 \%$ \\
\hline & other & $10.07 \%$ & $15.00 \%$ & $5.00 \%$ \\
\hline \multirow[t]{2}{*}{ Gender } & male & $48.16 \%$ & $47.40 \%$ & $48.33 \%$ \\
\hline & female & $51.84 \%$ & $52.50 \%$ & $51.66 \%$ \\
\hline \multirow[t]{5}{*}{ Age } & generation $\mathrm{Z}$ & $8.72 \%$ (age 18-22) & 9.84\% (age18-24) & $24.15 \%$ (age $18-34$ ) \\
\hline & millennials & $30.65 \%$ (age 23-38) & $17.00 \%$ (age $25-34$ ) & $38.62 \%$ (age $35-54)$ \\
\hline & generation $X$ & $26.02 \%$ (age 39-54) & $30.07 \%$ (age 35-54) & $34.60 \%$ (age $55 \&$ older) \\
\hline & boomer & $31.20 \%$ (age $55-73$ ) & $18.27 \%$ (age 55-74) & \\
\hline & silent & $3.41 \%$ (age 74 \& older) & $4.56 \%$ (age 75 \& older) & \\
\hline \multirow[t]{8}{*}{ Family Income } & Up to $\$ 19,999$ & $9.12 \%$ & $8.62 \%$ & $\mathrm{~N} / \mathrm{A}$ \\
\hline & $\$ 20,000-\$ 49,999$ & $20.68 \%$ & $18.99 \%$ & $\mathrm{~N} / \mathrm{A}$ \\
\hline & $\$ 50,000-\$ 74,999$ & $17.82 \%$ & $14.84 \%$ & $\mathrm{~N} / \mathrm{A}$ \\
\hline & $\$ 75,000-\$ 99,999$ & $15.92 \%$ & $13.06 \%$ & $\mathrm{~N} / \mathrm{A}$ \\
\hline & $\$ 100,000-\$ 124,999$ & $9.52 \%$ & $11.45 \%$ & $\mathrm{~N} / \mathrm{A}$ \\
\hline & $\$ 125,000-\$ 249,999$ & $14.29 \%$ & $18.87 \%(\$ 125 K-\$ 199 K)$ & $\mathrm{N} / \mathrm{A}$ \\
\hline & $\$ 250,000$ or over & $4.90 \%$ & $14.14 \%$ (\$200K \& up) & $\mathrm{N} / \mathrm{A}$ \\
\hline & DK/refused & $7.76 \%$ & $\mathrm{~N} / \mathrm{A}$ & $\mathrm{N} / \mathrm{A}$ \\
\hline \multirow[t]{4}{*}{ Education } & highschool or less & $11.16 \%$ & $28.90 \%$ & $25.57 \%$ \\
\hline & some college & $17.55 \%$ & $18.72 \%$ & $14.86 \%$ \\
\hline & college degree & $43.54 \%$ & $29.99 \%$ & $\begin{array}{c}58.95 \% \text { (college } \\
\text { graduate+) }\end{array}$ \\
\hline & advanced degree & $27.76 \%$ & $22.31 \%$ & \\
\hline
\end{tabular}

\subsection{Measures}

The primary objective of this study is to examine Asian Americans' perceptions of commonality with Blacks and Latinos. In the racial attitude literature, intergroup commonality has been conceptualized with several measures. Since early research on public opinion found that feelings of closeness toward a given group were important predictors of political support for that group (Berelson et al. 1954), the concept of perceived closeness has been used to estimate how similar respondents viewed themselves about their own group and in relation to different racial/ethnic groups (Craemer 2008; Jackman and Crane 1986; Thornton et al. 2013; Tropp 2007). For instance, Betina Cutaia Wilkinson (2015) used the perceived closeness question from the 2004 National Politics Survey to explain how and under what conditions, Whites, Latinos, and Blacks perceive commonality and competition with each other. Other scholars used a question with a general wording such as "just thinking about groups living in the United States, how much do you have in common with [race group]?" (Kaufmann 2003; Sanchez 2008; Wilkinson 2015 for focus group surveys) and "[do you agree or disagree with the following statement] Blacks and Latinos in America live by common values ... " (Glasford and Calcagno 2012). Recently, scholars have used a more specific concept to examine the context of commonality among racial and ethnic groups by using a political commonality measure. For example, respondents were asked to report how much in common they have with others when thinking about government services, political power, and representation (Gomez-Aguinaga et al. 2021; Huang 2021; Lu 2020a; Nicholson et al. 2020) or issues like job opportunities, educational attainment, or income (Jones-Correa et al. 2016; Wallsten and Nteta 2017). While the perceived closeness 
question is available in CEPPAAS, the latter two measures are not. Therefore, we used the following survey item to measure intergroup commonality among Asian Americans: "How close do you feel to each of the following groups of people in your ideas, interest, and feelings-Blacks and Latinos"? The responses were coded into a four-response scale: not close at all (0), not too close (1), fairly close (2), and very close (3).

Drawing upon the existing literature, the four key independent variables are included in the model. First, group consciousness has two measures to capture its multiple dimensions. It is a common practice for scholars to gauge group consciousness by multiple measures, and some of these measured dimensions have turned out to be statistically significant in explaining political behaviors and attitudes among individuals (McClain et al. 2009, p. 477). In the same manner, we used two survey items for this variable. The survey participants were asked how important they thought it was to "unite Asian Americans in order to gain political power" (the political power dimension) and to "work together to improve the position of their racial or ethnic group" (the collective action dimension)". Responses were coded into a four-response scale using the following values: not at all important (0), somewhat important (1), very important (2), and extremely important (3). Next, we measured group identity, also with two survey items. Respondents were asked how important the Asian race and ethnic/national origins are to their identification. Answers for both questions were also coded into a four-response scale: not important (0), somewhat important (1), very important (2), and extremely important (3). In the case of racial discrimination, we used the discrimination measurements used by Fan Lu (2020a). As CEPPAAS does not specifically ask respondents to assess experiential discrimination (personal discrimination) and the prevalence of racial discrimination against Asian Americans (group-based discrimination), we relied on a battery of "most important problem" questions to construct a proxy variable (Lu 2020a, p. 8). Asian Americans in our survey were prompted for their opinions on the most important and second-most important problems in the United States and in their personal lives, and these answers were combined to create a dichotomous variable for each dimension of discrimination experiences. The approximately $14 \%$ of respondents who listed "racism or racial discrimination" as the most important and the second most important problems scored 1 on group-based discrimination and personal discrimination while the remaining $86 \%$ scored 0 respectively. Lastly, intergroup contact was also measured with two survey items. We used respondents' answers for the racial composition of their neighborhoods and coded them into a fourpoint scale using the following values: mostly White (1), mostly Black or mostly Latino (2), mostly Asian (3), and mixed (4). Likewise, Asian Americans' interracial friendships were measured by using the same coding.

In addition to the independent variables, we included additional control variables measuring individual-level characteristics that have been found to influence interracial attitudes. Several basic demographic and socioeconomic factors such as gender, age, education, income, employment, and marital status are included in the model. In addition, political orientation such as party identification is included because liberal-leaning Asian Americans perceive higher levels of policy interest alignment with other racial groups (Arora et al. 2021; Ramakrishnan 2014; Wong and Shah 2021). Moreover, we include acculturation factors, such as nativity and length of stay because of the unique immigration nature of the Asian American community. The existing studies find that native-born Latinos perceive a higher level of commonality with Blacks and are more likely to be aware of the BLM movement (Corral 2020; Yellow Horse et al. 2021; Jones-Correa et al. 2016; Kaufmann 2003; Sanchez 2008; Wilkinson 2014). For acculturation, respondents' answers were recorded on a four-point scale with responses including 1 (American-born citizen), 2 (foreign-born citizen), 3 (noncitizen living in the United States for less than 5 years), and 4 (noncitizen living in the United States for more than 5 years). As a final control variable, respondents' national origin was operationalized as a seven-point scale indicating 1 (Chinese), 2 (Asian Indian), 3 (Filipino), 4 (Japanese), 5 (Korean), 6 (Vietnamese), and 7 (other ethnic groups). 
To examine the impact of four independent variables on Asian American intergroup commonality, we employed the ordered logistic regression models. The purpose of our research is to see how well Asian Americans' feelings of closeness to Blacks and Latinos can be predicted by their responses to group consciousness, group identity, perceptions of ingroup discrimination, and intergroup contact. As the dependent variable in this paper has a meaningful order with four categories, it is the most appropriate model to be used in our analysis.

\section{Results}

\subsection{Descriptive Statistics}

Table 2 provides sample characteristics of the dependent variables, the four independent variables, and the control variables in our model. For the sake of brevity, we present descriptive analyses of the dependent and independent variables as well as the remaining control variables, which were not included in Table 1.

To begin with, the descriptive analyses show that about half of Asian American respondents perceive commonality with Blacks (49.26\%) and Latinos (52.11\%). In particular, two-fifths of Asian Americans feel fairly close to Blacks (40.14\%) and Latinos (41.5\%) and one in ten Asian Americans express very close feelings toward outgroups (9.12\% toward Blacks and $10.61 \%$ toward Latinos). It is noticeable that Asian Americans' perceptions of commonality with outgroups tend to be moderate. Most Asian Americans either feel not too close to Blacks (38.64\%) and Latinos (34.01\%) or fairly close to them (about $40 \%$ for both racial groups). In other words, only two in ten respondents chose the answer options at the two extreme ends: no commonality at all or very close feelings to outgroups. This finding is in line with the recent research on intergroup commonality among Asian Americans that discovers a similar number of Asian Americans who perceive commonality with Blacks and Latinos (Yellow Horse et al. 2021; Lu 2020a; Nicholson et al. 2020).

Table 2. Descriptive statistics of variables $(N=735)$.

\begin{tabular}{lcc}
\hline Variable & & \\
\hline Dependent Variable & & \\
Intergroup Commonality & with Blacks & with Latinos \\
Not Close at all & $12.11 \%$ & $13.88 \%$ \\
Not Too Close & $38.64 \%$ & $34.01 \%$ \\
Fairly Close & $40.14 \%$ & $41.50 \%$ \\
Very Close & $9.12 \%$ & $10.61 \%$ \\
Independent Variables & & \\
Group Consciousness & Political Power & Collective Action \\
Not at all Important & $28.30 \%$ & $2.59 \%$ \\
Somewhat Important & $27.35 \%$ & $8.57 \%$ \\
Very Important & $26.39 \%$ & $44.90 \%$ \\
Extremely Important & $17.96 \%$ & $43.95 \%$ \\
Group Identity & Asian Identity & Ethnic Identity \\
Not at all Important & $6.94 \%$ & $17.01 \%$ \\
Somewhat Important & $18.64 \%$ & $20.68 \%$ \\
Very Important & $36.87 \%$ & $34.42 \%$ \\
Extremely Important & $37.55 \%$ & $27.89 \%$ \\
Views of Discrimination & Group-Based Discrimination & Personal Discrimination \\
Yes & $13.88 \%$ & $14.01 \%$ \\
Intergroup Contact & Racial Mix of Neighborhood & Racial Mix of Friendship \\
Mostly White & $39.18 \%$ & $20.00 \%$ \\
Mostly Black/Latino & $6.67 \%$ & $4.49 \%$ \\
Mostly Asian & $16.60 \%$ & $31.56 \%$ \\
Mostly Multiracial & $37.55 \%$ & $43.95 \%$ \\
\hline
\end{tabular}


Table 2. Cont.

\begin{tabular}{lc}
\hline Variable & \\
\hline Control Variables & \\
Acculturation & \\
$\quad$ U.S.-born citizen & $53.06 \%$ \\
$\quad$ Foreign-born citizen & $26.80 \%$ \\
$\quad$ Non-citizen; less than 5 & $9.39 \%$ \\
yrs $\quad$ & $10.74 \%$ \\
$\quad$ Non-citizen; more than 5 & \\
yrs $\quad$ \\
Employment & $43.81 \%$ \\
$\quad$ Not Working & $11.56 \%$ \\
$\quad$ Working Part-Time & $37.82 \%$ \\
$\quad$ Working Full-Time & $6.80 \%$ \\
$\quad$ Self-Employed & \\
Party Identification & $19.59 \%$ \\
$\quad$ Republican Party & $42.45 \%$ \\
Democratic Party & $18.91 \%$ \\
$\quad$ Independent & $19.05 \%$ \\
Not think in terms of & \\
political party & $40.00 \%$ \\
Marital Status & $43.95 \%$ \\
$\quad$ Not Married & $16.05 \%$ \\
Married with Asian &
\end{tabular}

Second, two measures of group consciousness display the interesting aspects of Asian Americans' views on what the racial group means to them. When they were asked if racial unity was important for achieving political power, Asian Americans were varied in their responses. The majority of Asian Americans think that racial unity is not at all important $(28.3 \%)$ or somewhat important at best (27.35\%). By contrast, Asian Americans show overwhelming support for collective action to improve the position of their own racial and ethnic group (88.85\%). Specifically, Asian Americans believe that working together beyond the internal diversity within the Asian American community is very important (44.9\%) or extremely important (43.95\%) to elevate its status in society. Only $11.16 \%$ of respondents in our sample disagree with the statement regarding the collective action dimension of group consciousness. This finding supports the scholarly consensus that this variable should be conceptualized with multiple measures to adequately gauge how racially conscious individuals really are (McClain et al. 2009).

Third, the descriptive statistics of Asian Americans show that identities based on both a racial category and national origins are important to the respondents. In general, $74.42 \%$ of respondents in this study identify themselves as Asian Americans, and the majority of Asian Americans also report that ethnic identity is meaningful to them (62.31\%). Yet there is a noticeable difference in the importance of racial and ethnic identities to Asian Americans. When we compare Asian American identities at the extreme categories, there is a roughly $10 \%$ gap. For instance, more Asian Americans think that ethnic identity is not important $(17.01 \%)$, compared to the respondents who think that Asian identity is not important (6.94\%). To put it differently, fewer Asian Americans think that ethnic identity is extremely important $(27.89 \%)$ in contrast to those respondents who consider Asian identity to be extremely important $(37.55 \%)$.

Next, intergroup contact measures also show intriguing results about the racial mix of Asian Americans' residential context and friendship. Most respondents describe their neighborhood as either mostly White $(39.18 \%)$ or mostly multiracial $(37.55 \%)$. When it comes to their friendships, however, Asian Americans are most likely to have multiracial friends (43.95\%) and Asian friends (31.56\%). Only one in five Asian Americans describes having friendships with mostly Whites. To put it differently, Asian Americans tend to live 
in the mostly White community, whereas their friends are mostly non-Whites. Noticeably, only a small percentage of Asian Americans live in the mostly Black or Latino residential areas and interact with mostly Black or Latino friends (6.67\% and 4.49\%, respectively).

The last independent variable tested in this study is perceptions of discrimination among Asian Americans. As explained in the previous section, we use the proxy variable based on the "most important problem" questions. A similar percentage of Asian Americans think that racial discrimination is the critical problem facing both this county and individual respondents (around 14\%).

One of the control variables unique to the Asian American community is acculturation, such as nativity and length of stay in the United States, because this group is a predominantly immigrant population. Regarding nativity, 53\% of Asian Americans in our data are natural-born citizens, and $26.8 \%$ of them are foreign-born citizens. Approximately $12 \%$ of the respondents hold a green card. According to the recent reports analyzing the 2017-2019 ACS, around six in ten Asian Americans (57\%) were born in another country (Budiman and Ruiz 2021), and immigrants from Asia are more likely than the overall foreign-born population to be naturalized citizens (Hanna and Batalova 2021). As the recent research on Asian American partisanship and vote choice reveals (Kuo et al. 2016; Masuoka et al. 2019; Raychaudhuri 2018; Zheng 2019), Asian Americans in this study also tend to identify themselves with the Democratic Party (42.45\%). However, a substantive percentage of respondents report that they are not affiliated with any political party $(18.91 \%)$ or do not think in terms of a political party $(19.05 \%)$, which is also in line with the previous findings (Aoki and Takeda 2008; Lien et al. 2004; Wong et al. 2011).

\subsection{Multivariate Results}

Table 3 presents the results of the ordered logistic regression models to explain how group consciousness, group identity, views of discrimination, and intergroup contact influence Asian Americans' interracial attitudes. Beginning with the role of group consciousness on Asian Americans' intergroup commonality, we find that a belief in collective action to improve the position of Asian Americans is associated with a stronger feeling of closeness to both Blacks and Latinos. Likewise, holding the belief that racial unity is important to increasing Asian American political power predicts higher levels of perceived commonality with Blacks, but the association is marginally significant $(p=<0.1)$.

Table 3. Ordered logistics regression coefficient results of Asian American interracial commonality $(N=735) .{ }^{* *} p<0.01$, ${ }^{* *} p<0.05, * p<0.1$.

\begin{tabular}{|c|c|c|c|c|}
\hline & $\begin{array}{c}\text { Commonality } \\
\text { Coefficient }\end{array}$ & $\begin{array}{c}\text { With Blacks } \\
\text { Std. Err. }\end{array}$ & $\begin{array}{c}\text { Commonality } \\
\text { Coefficient }\end{array}$ & $\begin{array}{l}\text { With Latinos } \\
\text { Std. Err. }\end{array}$ \\
\hline \multicolumn{5}{|c|}{ Group Consciousness } \\
\hline \multicolumn{5}{|c|}{ Political Power Dimension (ref. = not at all } \\
\hline Somewhat Important & -0.01 & $(0.19)$ & -0.02 & $(0.19)$ \\
\hline Very Important & $0.36 *$ & $(0.21)$ & 0.32 & $(0.21)$ \\
\hline Extremely Important & 0.37 & $(0.26)$ & 0.35 & $(0.26)$ \\
\hline \multicolumn{5}{|c|}{ Collective Action Dimension (ref. = not at all important and somewhat important) } \\
\hline Very Important & 0.40 & $(0.25)$ & 0.20 & $(0.25)$ \\
\hline Extremely Important & $0.76^{* * *}$ & $(0.26)$ & $0.77^{* * *}$ & $(0.26)$ \\
\hline \multicolumn{5}{|c|}{ Group Identity } \\
\hline \multicolumn{5}{|c|}{ Asian Identity (ref. = not at all important) } \\
\hline Somewhat Important & $-0.72 *$ & $(0.37)$ & -0.56 & $(0.36)$ \\
\hline Very Important & -0.52 & $(0.36)$ & -0.42 & $(0.35)$ \\
\hline Extremely Important & -0.48 & $(0.37)$ & -0.15 & $(0.36)$ \\
\hline
\end{tabular}


Table 3. Cont.

\begin{tabular}{|c|c|c|c|c|}
\hline & $\begin{array}{c}\text { Commonality } \\
\text { Coefficient }\end{array}$ & $\begin{array}{l}\text { With Blacks } \\
\text { Std. Err. }\end{array}$ & $\begin{array}{c}\text { Commonality } \\
\text { Coefficient }\end{array}$ & $\begin{array}{c}\text { With Latinos } \\
\text { Std. Err. }\end{array}$ \\
\hline \multicolumn{5}{|c|}{ Ethnic Identity (ref. = not at all important) } \\
\hline Somewhat Important & $0.52 *$ & $(0.27)$ & $0.74^{* * *}$ & $(0.27)$ \\
\hline Very Important & 0.40 & $(0.25)$ & $0.71^{* * *}$ & $(0.25)$ \\
\hline Extremely Important & $1.08^{* * *}$ & $(0.29)$ & $1.17^{* * *}$ & $(0.28)$ \\
\hline \multicolumn{5}{|l|}{ Views of Discrimination } \\
\hline \multicolumn{5}{|l|}{ Group Discrimination (ref. = no) } \\
\hline Yes & 0.24 & $(0.24)$ & -0.08 & $(0.23)$ \\
\hline \multicolumn{5}{|l|}{ Personal Discrimination (ref. = no) } \\
\hline Yes & -0.11 & $(0.23)$ & 0.06 & $(0.23)$ \\
\hline $\begin{array}{l}\text { Intergroup Contact } \\
\text { Racial Composition of Neighbo } \\
\text { (ref. = Mostly White) }\end{array}$ & & & & \\
\hline Mostly Black or Latino & 0.16 & $(0.33)$ & 0.47 & $(0.33)$ \\
\hline Mostly Asian & -0.09 & $(0.25)$ & 0.03 & $(0.25)$ \\
\hline Mostly Multiracial & 0.23 & $(0.18)$ & 0.24 & $(0.19)$ \\
\hline \multicolumn{5}{|l|}{$\begin{array}{l}\text { Racial Composition of Friendship } \\
\text { (ref. = Mostly White) }\end{array}$} \\
\hline Mostly Black or Latino & 0.62 & $(0.42)$ & $1.22 * * *$ & $(0.42)$ \\
\hline Mostly Asian & -0.30 & $(0.24)$ & 0.02 & $(0.24)$ \\
\hline Mostly Multiracial & $0.46^{* *}$ & $(0.22)$ & $0.60^{* * *}$ & $(0.22)$ \\
\hline \multicolumn{5}{|c|}{ Acculturation (ref. = U.S.-born citizen) } \\
\hline Foreign-born Citizen & -0.19 & $(0.19)$ & -0.16 & $(0.18)$ \\
\hline Non-citizen; less than 5 yrs & 0.29 & $(0.31)$ & 0.15 & $(0.31)$ \\
\hline Non-citizen; more than 5 yrs & 0.06 & $(0.26)$ & -0.14 & $(0.26)$ \\
\hline \multicolumn{5}{|l|}{ National Origin (ref. = Chinese) } \\
\hline Asian Indian & $1.19^{* * *}$ & $(0.26)$ & $0.72^{* * *}$ & $(0.26)$ \\
\hline Filipino & $0.53^{* *}$ & $(0.24)$ & $0.66^{* * *}$ & $(0.23)$ \\
\hline Japanese & 0.33 & $(0.25)$ & 0.36 & $(0.25)$ \\
\hline Korean & $0.80^{* * *}$ & $(0.30)$ & $0.57^{* *}$ & $(0.30)$ \\
\hline Vietnamese & $0.91^{* * *}$ & $(0.31)$ & $0.84^{* * *}$ & $(0.31)$ \\
\hline Other & 0.29 & $(0.30)$ & 0.47 & $(0.29)$ \\
\hline \multicolumn{5}{|l|}{ Gender (ref. = Male) } \\
\hline Female & $-0.31^{*}$ & $(0.17)$ & -0.07 & $(0.16)$ \\
\hline \multicolumn{5}{|c|}{ Generation (ref. = Generation Z; 18-22) } \\
\hline Millennials (23-38) & 0.18 & $(0.31)$ & -0.06 & $(0.32)$ \\
\hline Generation X (39-54) & 0.04 & $(0.32)$ & -0.04 & $(0.33)$ \\
\hline Boomer (55-73) & -0.02 & $(0.32)$ & -0.18 & $(0.33)$ \\
\hline Silent (74-91) & 0.10 & $(0.49)$ & 0.05 & $(0.49)$ \\
\hline \multicolumn{5}{|c|}{ Education (ref. = H.S. Degree or Lower) } \\
\hline Some College & 0.08 & $(0.28)$ & -0.03 & $(0.28)$ \\
\hline College Degree & -0.06 & $(0.27)$ & -0.14 & $(0.26)$ \\
\hline Advanced Degree & -0.33 & $(0.29)$ & -0.38 & $(0.29)$ \\
\hline \multicolumn{5}{|l|}{ Income (ref. = Less than $\$ 20,000$ ) } \\
\hline$\$ 20,000$ to $\$ 49,999$ & -0.08 & $(0.30)$ & 0.32 & $(0.30)$ \\
\hline$\$ 50,000$ to $\$ 74,999$ & -0.43 & $(0.32)$ & 0.27 & $(0.31)$ \\
\hline$\$ 75,000$ to $\$ 99,999$ & -0.18 & $(0.33)$ & 0.42 & $(0.32)$ \\
\hline$\$ 100,000$ to $\$ 124,999$ & -0.29 & $(0.37)$ & 0.41 & $(0.37)$ \\
\hline$\$ 125,000$ to $\$ 249,999$ & -0.09 & $(0.35)$ & 0.43 & $(0.35)$ \\
\hline$\$ 250,000$ or over & $-0.85 *$ & $(0.44)$ & -0.13 & $(0.44)$ \\
\hline DK/Refused & $-0.63 *$ & $(0.36)$ & -0.25 & $(0.36)$ \\
\hline \multicolumn{5}{|l|}{ Employment (ref. = Not Working) } \\
\hline Working Part-Time & 0.08 & $(0.18)$ & 0.23 & $(0.18)$ \\
\hline Working Full-Time & 0.14 & $(0.25)$ & 0.16 & $(0.24)$ \\
\hline Self-Employed & 0.06 & $(0.31)$ & 0.06 & $(0.32)$ \\
\hline
\end{tabular}


Table 3. Cont

\begin{tabular}{lcccc}
\hline & $\begin{array}{c}\text { Commonality } \\
\text { Coefficient }\end{array}$ & $\begin{array}{c}\text { With Blacks } \\
\text { Std. Err. }\end{array}$ & $\begin{array}{c}\text { Commonality } \\
\text { Coefficient }\end{array}$ & $\begin{array}{c}\text { With Latinos } \\
\text { Std. Err. }\end{array}$ \\
\hline Marital Status (ref. = Not Married) & & & & \\
$\quad$ Married/Cohabiting with Asian & 0.12 & $(0.19)$ & -0.02 & $(0.19)$ \\
$\quad$ Married/Cohabiting with non-Asian & -0.03 & $(0.24)$ & 0.14 & $(0.24)$ \\
Party Identification (ref. = Republican) & & & & \\
Democrat & $0.54^{* *}$ & $(0.20)$ & $0.78^{* * *}$ & $(0.21)$ \\
Independent & 0.18 & $(0.24)$ & $0.57^{* *}$ & $(0.24)$ \\
Not think in terms of party & 0.35 & $(0.25)$ & $0.77^{* * *}$ & $(0.25)$ \\
/ cut1 & -0.87 & $(0.58)$ & 0.39 & $(0.57)$ \\
/cut2 & 1.43 & $(0.58)$ & 2.39 & $(0.58)$ \\
/ cut3 & 4.02 & $(0.60)$ & 4.94 & $(0.60)$ \\
\hline
\end{tabular}

For the second theory about group identity, we discover that pan-ethnic identity as an Asian does not increase the levels of intergroup commonality for Asian Americans. Instead, there is a negative relationship between the two. Although it is weakly associated $(p=<0.1)$, respondents who report that Asian identity is somewhat important are less likely to feel closeness to Blacks than those who view a racial identity as not important at all. However, there is a relationship between ethnic identity and Asian American intergroup commonality. Respondents who consider their national origins to be somewhat important or extremely important are more likely to report interracial commonality with Black Americans. Asian Americans' feeling of closeness to Latinos is also associated with their ethnic identity. A strong ethnic identity (all three response categories of somewhat important, very important, and extremely important) indeed results in a higher perception of commonality with Latinos among Asian Americans.

The results pertaining to intergroup contact are not significant for the racial composition of the neighborhood but are significant for interracial friendship. Compared to Asian Americans, who live in the mostly White community, those living in the mostly Black or Latino neighborhood, or the multiracial residential area, do not necessarily have an increased likelihood of perceiving commonality with Blacks and Latinos. However, there is an association between a racial mix of friendship and Asian Americans' feeling of closeness with outgroups. The likelihood of perceiving commonality with Blacks $(p=<0.05)$ and Latinos $(p=<0.01)$ is increased among those respondents whose friends are mostly multiracial. In addition, having Black or Latino friends is associated with Asian Americans' perceived commonality with Latinos, whereas having mostly Asian friends makes their feeling of closeness to outgroups almost no different than for those respondents whose friends are mostly Whites.

While we find a statistical relationship for three independent variables, results about Asian Americans' views of discrimination do not offer such association. Neither experiential discrimination nor recognition of group-based discrimination necessarily increases Asian Americans' perceptions of commonality with Blacks and Latinos.

When a variety of demographic factors are tested, two control variables turn out to be significant in explaining Asian American intergroup commonality. First, the national origin category shows the intriguing result that non-Chinese Asian Americans are generally more likely to perceive commonality with Blacks and Latinos than Chinese Americans. In particular, Asian Indians, Filipino Americans, Korean Americans, and Vietnamese Americans are more likely to feel close to Blacks and Latinos than Chinese Americans. Second, party identification is strongly associated with Asian American intergroup commonality. Respondents who are identified with the Democratic Party are strongly more likely to perceive commonality with Blacks and Latinos ( $p=0.01$ for both) than their Republican counterparts within the group. Asian Americans who are politically independent $(p=<0.05)$, as well as those who do not think in terms of political parties $(p=<0.01)$, are also more likely to feel close to Latinos. This supports the prior findings that Asian Americans who are Democrats 
tend to support the BLM movement (Merseth 2018; Yellow Horse et al. 2021) as well as to perceive higher levels of commonality with outgroups (Arora et al. 2021).

The remaining demographic variables are statistically insignificant to predict Asian American intergroup commonality. Although female respondents are less likely to perceive commonality with Blacks than their male counterparts, gender is not associated with Asian Americans' feelings of closeness to Latinos. A higher income is only weakly associated with Asian Americans' attitudes toward Blacks, but it is not significant for their perceived commonality with Latinos. In addition, we discover that acculturation, generation, employment, educational attainment, and marital status are not influential to Asian Americans' feelings of closeness to outgroups.

\section{Discussion and Conclusions}

Many people believe that commonality is the necessary symbolic glue for a sustained minority coalition (Kaufmann 2003, p. 206). While studies about a Black-Brown alliance are well developed, scholarly attention to the roles of Asian Americans for such alliance is nascent. As one of a few attempts to study interracial attitudes among Asian Americans, this paper contributes to expanding our understanding of the opportunities and constraints for Asian Americans to join a rainbow coalition. The evidence in this paper suggests that group consciousness, ethnic identity, and intergroup contact contribute to Asian Americans ${ }^{\prime}$ perception of commonality with Blacks and Latinos.

First, we found that support for a collective action within the Asian American population to improve their social position is strongly associated with Asian Americans' feeling of closeness to Blacks and Latinos. For Asian Americans with a strong belief in collective work among ingroup members, improving the social position of their ingroup could mean achieving social justice and racial equality (Yellow Horse et al. 2021). As these are goals shared by other minority groups, Asian Americans may perceive more commonality with Blacks and Latinos. However, another measure of group consciousness-the belief that racial unity is important to increasing the political power of Asian Americans-is only weakly associated with Asian Americans' interracial attitudes. This finding is consistent with the extant research that group consciousness should be activated to shape intergroup commonality for positive inter-minority relations (Lin 2020; Nicholson et al. 2020).

Second, we uncovered the fact that Asian Americans' ethnic identity is strongly associated with higher levels of perceptions of interracial commonality, but not pan-ethnic Asian identity. Although it was not statistically significant (except for one response category of "somewhat important" for commonality with Blacks), Asian identity is negatively associated with feelings of closeness to Blacks and Latinos. There are several possible explanations for the opposite effects of group identity measures on intergroup commonality. On the one hand, ethnic identity may activate respondents' awareness of their minority status, which leads them to perceive commonality with other underprivileged groups such as Blacks and Latinos. Previous studies have shown that income inequality and the reported personal experiences of discrimination are significantly varied across Asian ethnic groups and that these problems have occurred at a higher rate among Southeast Asians who have darker skins. Thus, Asian respondents with a strong ethnic identity may be more likely to feel close to the disadvantaged groups. On the other hand, a strong racial identity as an Asian American may solidify the ingroup commonality only. They may perceive commonality with none of the outgroups, but only with Asian Americans. Or they may feel close to Whites than Blacks or Latinos. The previous data showed a slightly higher level of perceived commonality between Asian Americans and Whites (Ramakrishnan et al. 2008). Although it is beyond the scope of this study, future researchers need to fully examine why two measures of group identity work differently for explaining Asian Americans' intergroup commonality. 
Next, this study discovers that there is a strong positive relationship between interracial friendship and Asian Americans' perception of commonality with outgroups. Having Black, Latino, or multiracial friends increases Asian Americans' feeling of closeness to Blacks and Latinos. This finding supports the existing studies about the importance of intergroup contact to shape interracial attitudes amongst minority groups (Ellison and Powers 1994; Sigelman and Welch 1993; Wilkinson 2014). It is noticeable that another measure of intergroup contact - the racial makeup of neighborhoods in which respondents live-turns out not to be statistically significant to explain Asian Americans' intergroup commonality. This finding implies that there should be direct interaction with outgroup members in the interpersonal setting to be significant in shaping Asian Americans' positive attitudes toward outgroups, not just the racial composition of the residential environment.

Finally, we found that neither group-based discrimination nor personal discrimination is associated with Asian Americans' intergroup commonality. For Asian Americans, beliefs about discrimination may not necessarily trigger the same feelings of being the victims of systematic racism in the United States shared by other minority groups, such as Blacks and Latinos. As we will discuss in the next section, this null finding may be explained for misuse of the proxy variable. If not, it may truly mean that perceived discrimination against one's own group is not associated with Asian Americans' perceptions of commonality with Blacks and Latinos. As Merseth (2018) found, what really matters for Asian Americans' intergroup commonality can be whether they perceive discrimination against Blacks and Latinos.

Despite the contributions, there are a few limitations. This study is limited by the type and number of questions about interminority relations. First, the dependent variable is somewhat narrowly measured in this study. Although generalized feelings of closeness have been especially useful for assessing interracial attitudes (Thornton et al. 2013), another measure, such as the perception of political commonality, should be also used as this question specifically examine how respondents view themselves in relation to out-groups in political contexts. Second, while we used two measures of political power and collective work to reflect the multi-dimensional nature of group consciousness, the conventional measure of linked fate could be added to improve the statistical analysis (Sanchez and Vargas 2016). Next, the null finding regarding perceptions of discrimination should be carefully interpreted, as it could result from poor proxy measures. Due to limitations in the survey questionnaire, we replicated Fan Lu's (2020a) approach to using the "most important problem" questions for this independent variable. While Lu (2020a) also discovers no relationship between group-based discrimination and Asian Americans' perceived commonality with Latinos, she offers the possibility that proxy measures may be poorly constructed to capture theoretical concepts about the roles of discrimination experiences. Moreover, the role that discrimination experiences play in Asian Americans' interminority closeness can be fully explained if different contexts, such as interpersonal discrimination, employment-related discrimination, and residential discrimination, are tested in the model (Corral 2020; Huang 2021; Lu 2020a). The final note on limitation is that this research by no means provides a causal relationship between the dependent variable and the four independent variables. Like most existing studies about intergroup commonality among minority groups, we utilized a cross-sectional survey, so we cannot make causal claims about the associations among intergroup commonality, group consciousness, group identity, perceptions of discrimination, and intergroup contact (Yellow Horse et al. 2021, p. 15).

We believe that this study offers some important lessons for future research. First, more scholarly attention should be paid to examining the critical roles that CBOs can play in cross-racial coalitions. Our finding suggests that direct interaction with outgroup members in interpersonal settings is strongly associated with higher levels of perceived commonality with Blacks and Latinos. When only half of Asian Americans tend to feel close to Blacks and Latinos, promoting positive direct contact between Asian Americans and other minority groups will be critical to establishing a foundation for inter-minority alliances. Some 
existing studies present the ways in which CBOs in California were able to bring Asian Americans together for racial coalition-building by operating various community programs and outreach efforts involving close interaction among minority groups (Hope 2019; Kim and Lee 2001; Lin 2020; Okamoto and Gast 2013; Ramakrishnan 2014). For sustainable rainbow coalitions, it is important to investigate if and how $\mathrm{CBO}$ in other states also work toward this common goal.

Second, future scholars should fully examine the effects of ethnic identity and ethnic variations on Asian Americans' feelings of closeness to outgroups. Our finding that respondents' strong ethnic identity is associated with Asian Americans' perceived commonality with outgroups is consistent with a recent study highlighting the importance of understanding Asian Americans by national origins for cross-racial collaboration (Arora et al. 2021). In their attempt to identify opportunities and constraints for inter-minority coalitions, Arora and his colleagues (2021) argue that certain ethnic groups such, as Chinese, Japanese, and Vietnamese Americans, face greater constraints to forming such coalitions due to incongruence in their policy positions with Blacks and Latinos than other Asian ethnic groups. Similarly, this study discovers considerable variation among Asian American national origin groups in terms of their interracial attitudes, ranging from Chinese Americans as the most conservative to Asian Indians as the most liberal. To form a sustainable cross-racial collaboration, it is necessary to fully explore the process whereby ethnic identity influences Asian Americans' perceptions of intergroup commonality and what national origin groups have the greatest opportunity to join a rainbow coalition with such perceptions.

Funding: This study is supported by the College of Letters and Science at the University of WisconsinStevens Point under the start-up fund granted to the corresponding author. This research is also supported by the Office of Research and Sponsored Programs at UWSP for the publication fund.

Institutional Review Board Statement: The study was conducted according to the guidelines of the Declaration of Helsinki, and approved by the Institutional Review Board of University of WisconsinStevens Point (protocol \#: 16-17.071; date of approval: 7 March 2018).

Informed Consent Statement: Informed consent was obtained from all subjects involved in the study.

Data Availability Statement: The data that support the findings of this study could be available from the corresponding author, upon reasonable request.

Conflicts of Interest: The author declares no potential conflict of interest with respect to the research, authorship, and/or publication of this article.

\section{References}

Allen, Richard L., Michael C. Dawson, and Ronald E. Brown. 1989. A Schema-Based Approach to Modeling an African-American Racial Belief System. American Political Science Review 83: 421-41. [CrossRef]

Aoki, Andrew, and Okiyoshi Takeda. 2008. Asian American Politics. Malden: Polity Press.

Arora, Maneesh, and Christopher T. Stout. 2019. Letters for Black Lives: Co-Ethnic Mobilization and Support for the Black Lives Matter Movement. Political Research Quarterly 72: 389-402. [CrossRef]

Arora, Maneesh, Sara Sadhwani, and Sono Shah. 2021. Unpacking Identity: Opportunities and Constraints for Cross-Racial Collaboration. RSF: The Russell Sage Foundation Journal of the Social Sciences 7: 93-110. [CrossRef]

Austin, Sharon D. Wright, Richard T. Middleton, and Rachel Yon. 2012. The Effect of Racial Group Consciousness on the Political Participation of African Americans and Black Ethnics in Miami-Dade County, Florida. Political Research Quarterly 65: 629-41. [CrossRef]

Berelson, Bernard R., Paul F. Lazarsfeld, and William N. McPhee. 1954. Voting. Chicago: The University of Chicago Press.

Bobo, Lawrence, and Vincent L. Hutchings. 1996. Perceptions of Racial Group Competition: Extending Blumer's Theory of Group Position to a Multiracial Social Context. American Sociological Review 61: 951-72. [CrossRef]

Bobo, Lawrence, Camille Zubrinsky, James Johnson, and Melvin Oliver. 1994. Public Opinion before and after a Spring of Discontent. In The Los Angeles Riots. Edited by Mark Baldassare. Boulder: Westview Press.

Bonilla, Tabitha, and Alvin B. Tillery. 2020. Which Identity Frames Boost Support for and Mobilization in the \#BlackLivesMatter Movement? An Experimental Test. American Political Science Review 114: 947-62. [CrossRef]

Broman, Clifford L., Harold W. Neighbors, and James S. Jackson. 1988. Racial Group Identification Among Black Adults. Social Forces 67: 146-58. [CrossRef] 
Budiman, Abby, and Neil G. Ruiz. 2021. Key Facts about Asian Origin Groups in the U.S. Pew Research Center. April 29. Available online: https:/ / www.pewresearch.org/fact-tank/2021/04/29/key-facts-about-asian-origin-groups-in-the-u-s/ (accessed on 28 July 2021).

Cho, Richard. 2020. The effect of minority identity convergence on pan-ethnicity among Asian Americans. Politics, Groups, and Identities 8: 453-70. [CrossRef]

Corral, Álvaro J. 2020. Allies, Antagonists, or Ambivalent? Exploring Latino Attitudes about the Black Lives Matter Movement. Hispanic Journal of Behavioral Sciences 42: 431-54. [CrossRef]

Craemer, Thomas. 2008. Nonconscious Feelings of Closeness toward African Americans and Support for Pro-Black Policies. Political Psychology 29: 407-36. [CrossRef]

Craig, Maureen A., and Jennifer A. Richeson. 2012. Coalition or derogation? How perceived discrimination influences intraminority intergroup relations. Journal of Personality and Social Psychology 102: 759-77. [CrossRef] [PubMed]

Dawson, Michael C. 1994. Behind the Mule: Race and Class in African-American Politics. Princeton: Princeton University Press.

Drouhot, Lucas G., and Filiz Garip. 2021. What's Behind a Racial Category? Uncovering Heterogeneity Among Asian Americans Through a Data-Driven Typology. RSF: The Russell Sage Foundation Journal of the Social Sciences 7: 22-45. [CrossRef]

Ellison, Christopher G., and Daniel A. Powers. 1994. The contact hypothesis and racial attitudes among Black Americans. Social Science Quarterly 75: 385-400.

Frey, William. 2018. The US Will Become 'Minority White' in 2045, Census Projects. March 14. Available online: https://www. brookings.edu/blog/the-avenue/2018/03/14/the-us-will-become-minority-white-in-2045-census-projects / (accessed on 28 July 2021).

Gaertner, Samuel L., Mary C. Rust, John F. Dovidio, Betty A. Bachman, and Phyllis A. Anastasio. 1994. The Contact Hypothesis: The Role of a Common Ingroup Identity on Reducing Intergroup Bias. Small Group Research 25: 224-49. [CrossRef]

Glasford, Demis E., and Justine Calcagno. 2012. The conflict of harmony: Intergroup contact, commonality and political solidarity between minority groups. Journal of Experimental Social Psychology 48: 323-28. [CrossRef]

Gomez-Aguinaga, Barbara, Gabriel R. Sanchez, and Matt Barreto. 2021. Importance of State and Local Variation in Black-Brown Attitudes: How Latinos View Blacks and How Blacks Affect Their Views. The Journal of Race, Ethnicity, and Politics 6: $214-52$. [CrossRef]

Gover, Angela, Shannon Harper, and Lynn Langton. 2020. Anti-Asian Hate Crime During the COVID-19 Pandemic: Exploring the Reproduction of Inequality. American Journal of Criminal Justice 45: 647-67. [CrossRef]

Hackman, Michelle. 2020. How Trump has worked to restrict immigration: The president has sought to curb both legal and illegal immigration, a central theme of his administration. The Wall Street Journal. June 18. Available online: https://www.wsj.com/ articles/how-trump-has-worked-to-restrict-immigration-11592491276 (accessed on 20 July 2021).

Hanna, Mary, and Jeanne Batalova. 2021. Immigrants from Asia in the United States. Washington, DC: Migration Policy Institute, March 10. Available online: https://www.migrationpolicy.org/article/immigrants-asia-united-states-2020 (accessed on 8 August 2021)

Herrick, Rebekah, and Jeanette Morehouse Mendez. 2019. One Model Does Not Fit All: Group Consciousness and the Political Participation and Attitudes of American Indians. Social Science Quarterly 100: 1577-92. [CrossRef]

Hope, Jeanelle K. 2019. This Tree Needs Water!: A Case Study on the Radical Potential of Afro-Asian Solidarity in the Era of Black Lives Matter. Amerasia Journal 45: 222-37. [CrossRef]

Huang, Tiffany J. 2021. Perceived Discrimination and Intergroup Commonality Among Asian Americans. RSF: The Russell Sage Foundation Journal of the Social Sciences 7: 180-200. [CrossRef]

Israel-Trummel, Mackenzie L., and Ariela Schachter. 2019. Does Shared Social Disadvantage Cause Black-Latino Political Commonality? Journal of Experimental Political Science 6: 43-52. [CrossRef]

Jackman, Mary R., and Marie Crane. 1986. “Some of my best friends are black ... ": Interracial Friendship and Whites' Racial Attitudes. Public Opinion Quarterly 50: 459-86. [CrossRef]

Jennings, James. 1994. Racial Hierarchy and Ethnic Conflict in the United States. In Blacks, Latinos, and Asians in Urban America: Status and Prospects for Politics and Activism. Edited by James Jennings. Westport: Praegar.

Jo, Moon. 1992. Korean merchants in the black community: Prejudice among the victims of prejudice. Ethnic and Racial Studies 15: 395-411. [CrossRef]

Johnson, Kevin R. 2004. Law and Politics in Post-modern California: Coalition or Conflict between African Americans, Asian Americans, and Latina/os? Ethnicities 4: 381-401. [CrossRef]

Jones-Correa, Michael, Sophia Wallace, and Chris Zepeda-Millán. 2016. The Impact of Large-Scale Collective Action on Latino Perceptions of Commonality and Competition with African Americans. Social Science Quarterly 97: 458-75. [CrossRef]

Junn, Jane, and Natalie Masuoka. 2008. Asian American Identity: Shared Racial Status and Political Context. Perspectives on Politics 6: 729-40. [CrossRef]

Kaufmann, Karen M. 2003. Cracks in the Rainbow: Group Commonality as a Basis for Latino and African-American Political Coalitions. Political Research Quarterly 56: 199-210. [CrossRef]

Kim, Claire Jean. 1999. The Racial Triangulation of Asian Americans. Politics and Society 27: 105-58. [CrossRef]

Kim, Claire Jean. 2000. Bitter Fruit: The Politics of Black-Korean Conflict in New York City. New Have: Yale University Press.

Kim, Nadia. 2004. A View from Below: An Analysis of Korean Americans' Racial Attitudes. Amerasia Journal 30: 1-24. [CrossRef] 
Kim, Claire Jean, and Taeku Lee. 2001. Interracial Politics: Asian Americans and Other Communities of Color. PS: Political Science and Politics 34: 631-37. Available online: http:/ / www.jstor.org/stable/1353551 (accessed on 15 September 2021).

Koch, Nadine, and H. Eric Schockman. 1994. Riot, Rebellion, or Civil Unrest?: The Korean American and the African American Business Communities in Los Angeles. In Community in Crisis. Edited by George Totten and H. Eric Schockman. Los Angeles: Center for Multi-ethnic and Transnational Studies, University of Southern California.

Kuo, Alexander, Neil Malhotra, and Cecilia Hyunjung Mo. 2016. Social Exclusion and Political Identity: The Case of Asian American Partisanship. Center for the Study of Democratic Institutions. Nashville: Vanderbilt University. Available online: https: //www.vanderbilt.edu/csdi/includes/Mo_workingpaper_1_2016.pdf (accessed on 23 October 2021).

Kwon, Haeyoung, and Wayne Au. 2010. Model Minority Myth. In Encyclopedia of Asian American Issues Today. Edited by Chen Wen-Chu, Grace J. Yoo and Wendy Ng. Santa Barbara: Greenwood Press, pp. 221-30.

Le, Denvy, Maneesh Arora, and Christopher Stout. 2020. Are You Threatening Me? Asian-American Panethnicity in the Trump Era. Social Science Quarterly 101: 2183-92. [CrossRef] [PubMed]

Lee, Taeku. 2000. Racial Attitudes and the Color Line(s) at the Close of the Twentieth Century. In Transforming Race Relations: A Public Policy Report. Edited by Paul M. Ong. Los Angeles: LEAP Asian Pacific American Public Policy Institute and UCLA Asian American Studies Center.

Lee, Stacey, Choua Xiong, Linda Pheng, and Mai Neng Vang. 2020. "Asians for Black Lives, Not Asians for Asians": Building Southeast Asian American and Black Solidarity. Anthropology \& Education Quarterly 51: 405-21. [CrossRef]

Lien, Pei-te, Margaret Conway, and Janelle Wong. 2003. The Contours and Sources of Ethnic Identity Choices Among Asian Americans. Social Science Quarterly 84: 461-81. [CrossRef]

Lien, Pei-te, Margaret Conway, and Janelle Wong. 2004. The Politics of Asian Americans: Diversity and Community. New York: Routledge.

Lin, May. 2020. From alienated to activists: Expressions and formation of group consciousness among Asian American young adults. Journal of Ethnic and Migration Studies 46: 1405-424. [CrossRef]

Liu, Wen. 2018. Complicity and Resistance: Asian American Body Politics in Black Lives Matter. Journal of Asian American Studies 21: 421-51. [CrossRef]

Lu, Fan. 2020a. Forging ties: The effect of discrimination on Asian Americans' perceptions of political commonality with Latinos. Politics, Groups, and Identities 8: 595-614. [CrossRef]

Lu, Fan. 2020b. The Dual Identity of Asian Americans. Social Science Quarterly 101: 1869-84. [CrossRef]

Lu, Fan, and Bradford Jones. 2019. Effects of belief versus experiential discrimination on race-based linked fate. Politics, Groups, and Identities 7: 615-24. [CrossRef]

Martinez-Ebers, Valerie, Brian Robert Calfano, and Regina Branton. 2021. Bringing People Together: Improving Intergroup Relations via Group Identity Cues. Urban Affairs Review 57: 104-27. [CrossRef]

Masuoka, Natalie. 2006. Together They Become One: Examining the Predictors of Panethnic Group Consciousness Among Asian Americans and Latinos. Social Science Quarterly 87: 993-1011. [CrossRef]

Masuoka, Natalie. 2008. Defining the Group: Latino Identity and Political Participation. American Politics Research 36: 33-61. [CrossRef]

Masuoka, Natalie, Kumar Ramanathan, and Jane Junn. 2019. New Asian American Voters: Political Incorporation and Participation in 2016. Political Research Quarterly 72: 991-1003. [CrossRef]

McClain, Paula D., Jessica D. Johnson Carew, Eugene Walton Jr., and Candis S. Watts. 2009. Group Membership, Group Identity, and Group Consciousness: Measures of Racial Identity in American Politics? Annual Review of Political Science 12: 471-85. [CrossRef]

Merseth, Julie Lee. 2018. Race-ing solidarity: Asian Americans and support for Black Lives Matter. Politics, Groups, and Identities 6: 337-56. [CrossRef]

Min, Pyong Gap. 1996. Caught in the Middle: Korean Communities in New York and Los Angeles. Berkeley: University of California Press.

Min, Tae Eun. 2014. The Impact of Panethnicity on Asian American and Latino Political Participation. Ethnicities 14: 698-721. [CrossRef]

Morris, Frank, and James G. Gimpel. 2007. Immigration, Intergroup Conflict, and the Erosion of African American Political Power in the 21st Century. Washington, DC: Center for Immigration Studies. Available online: https://cis.org/sites/cis.org/files/articles/2007 /back207.pdf (accessed on 14 October 2021).

Nicholson, Harvey L., J. Scott Carter, and Arjee Restar. 2020. Strength in Numbers: Perceptions of Political Commonality with African Americans among Asians and Asian Americans in the United States. Sociology of Race and Ethnicity 6: 107-22. [CrossRef]

Okamoto, Dina, and Melanie Jones Gast. 2013. Racial Inclusion or Accommodation: Expanding Community Boundaries among Asian American Organizations. Du Bois Review: Social Science Research on Race 10: 131-53. [CrossRef]

Oliver, Eric, and Janelle Wong. 2003. Intergroup Prejudice in Multiethnic Settings. American Journal of Political Science 47: 567-82. [CrossRef]

Pew Research Center. 2013. The Rise of Asian Americans. Last Updated in 4 April 2013. Available online: https://www.pewresearch. org/social-trends/2012/06/19/the-rise-of-asian-americans / (accessed on 14 October 2021).

Phillips, Christian Dyogi, and Taeku Lee. 2018. Superficial Equality: Gender and immigration in Asian American political participation. Politics, Groups, and Identities 6: 373-88. [CrossRef]

Phoenix, Davin L., and Maneesh Arora. 2018. From emotion to action among Asian Americans: Assessing the roles of threat and identity in the age of Trump. Politics, Groups, and Identities 6: 357-72. [CrossRef]

Ramakrishnan, Karthick. 2014. Asian Americans and the rainbow: The prospects and limits of coalitional politics. Politics, Groups, and Identities 2: 522-29. [CrossRef] 
Ramakrishnan, Karthick, Jane Junn, Kaeku Lee, and Janelle Wong. 2008. National Asian American Survey. Inter-University Consortium for Political and Social Research. Available online: https://www.icpsr.umich.edu/web/RCMD/studies/31481 (accessed on 6 September 2021).

Raychaudhuri, Tanika. 2018. The social roots of Asian American partisan attitudes. Politics, Groups, and Identities 6: 389-410. [CrossRef]

Rim, Kathy H. 2009. Racial Context Effects and the Political Participation of Asian Americans. American Politics Research 37: 569-92. [CrossRef]

Sakamoto, Arthur, Isao Takei, and Hyeyoung Woo. 2012. The Myth of the Model Minority Myth. Sociological Spectrum 32: 309-21. [CrossRef]

Samson, Frank L. 2015. Asian American Attitudes towards a US Citizenship Path for Illegal Immigrants: Immigration Reform as Racialised Politics. Journal of Ethnic and Migration Studies 41: 117-37. [CrossRef]

Sanchez, Gabriel R. 2006. The Role of Group Consciousness in Latino Public Opinion. Political Research Quarterly 59: 435-46. [CrossRef]

Sanchez, Gabriel R. 2008. Latino Group Consciousness and Perceptions of Commonality with African Americans. Social Science Quarterly 89: 428-44. [CrossRef]

Sanchez, Gabriel R., and Natalie Masuoka. 2010. Brown-Utility Heuristic? The Presence and Contributing Factors of Latino Linked Fate. Hispanic Journal of Behavioral Sciences 32: 519-31. [CrossRef]

Sanchez, Gabriel R., and Edward D. Vargas. 2016. Taking a Closer Look at Group Identity: The Link between Theory and Measurement of Group Consciousness and Linked Fate. Political Research Quarterly 69: 160-74. [CrossRef] [PubMed]

Sanchez, Gabriel R., Natalie Masuoka, and Brooke Abrams. 2019. Revisiting the brown-utility heuristic: A comparison of Latino linked fate in 2006 and 2016. Politics, Groups, and Identities 7: 673-83. [CrossRef]

Sigelman, Lee, and Susan Welch. 1993. The Contact Hypothesis Revisited: Black-White Interaction and Positive Racial Attitudes. Social Forces 71: 781-95. [CrossRef]

Stokes, Atiya Kai. 2003. Latino Group Consciousness and Political Participation. American Politics Research 31: 361-78. [CrossRef]

Stokes-Brown, Atiya Kai. 2006. Racial Identity and Latino Vote Choice. American Politics Research 34: 627-52. [CrossRef]

Stokes-Brown, Atiya Kai. 2009. The Hidden Politics of Identity: Racial Self-Identification and Latino Political Engagement. Politics \& Policy 37: 1281-305. [CrossRef]

Tessler, Hannah, Meera Choi, and Grace Kao. 2020. The Anxiety of Being Asian American: Hate Crimes and Negative Biases During the COVID-19 Pandemic. American Journal of Criminal Justice 45: 636-46. [CrossRef]

Thornton, Michael C., Robert Joseph Taylor, and Linda M. Chatters. 2013. African American and Black Caribbean Mutual Feelings of Closeness: Findings From a National Probability Survey. Journal of Black Studies 44: 798-828. [CrossRef]

Tokeshi, Matthew. 2021. Anti-black Prejudice in Asian American Public Opinion. Politics, Groups, and Identities. [CrossRef]

Tropp, Linda. 2007. Perceived Discrimination and Interracial Contact: Predicting Interracial Closeness among Black and White Americans. Social Psychology Quarterly 70: 70-81. [CrossRef]

U.S. Census Bureau. 2015. American Community Survey; Washington, DC: U.S. Census Bureau.

Vang, Ma, and Kit Myers. 2021. In the Wake of George Floyd: Hmong Americans' Refusal to Be a U.S. Ally. Amerasia Journal, 1-15. [CrossRef]

Vespa, Jonathan, Lauren Medina, and David M. Armstrong. 2020. Demographic Turning Points for the United States: Population Projections for 2020 to 2060; Current Population Reports. P25-1144; Washington, DC: U.S. Census Bureau. Available online: https:/ / www.census.gov/content/dam/Census/library/publications/2020/demo/p25-1144.pdf (accessed on 6 July 2021).

Wallsten, Kevin, and Tatishe M. Nteta. 2017. Race, partisanship, and perceptions of inter-minority commonality. Politics, Groups, and Identities 5: 298-320. [CrossRef]

Weitzer, Ronald. 1997. Racial Prejudice among Korean Merchants in African American Neighborhoods. Sociological Quarterly 38: 587-606. [CrossRef]

Wilkinson, Betina Cutaia. 2014. Perceptions of Commonality and Latino-Black, Latino-White Relations in a Multiethnic United States. Political Research Quarterly 67: 905-16. [CrossRef]

Wilkinson, Betina Cutaia. 2015. Partners or Rivals? Charlottesville: University of Virginia Press.

Wong, Janelle, and Sono Shah. 2021. Convergence Across Difference: Understanding the Political Ties That Bind with the 2016 National Asian American Survey. RSF: The Russell Sage Foundation Journal of the Social Sciences 7: 70-92. [CrossRef]

Wong, Janelle S., Pei-Te Lien, and M. Margaret Conway. 2005. Group-Based Resources and Political Participation among Asian Americans. American Politics Research 33: 545-76. [CrossRef]

Wong, Janelle, S. Karthick Ramakrishnan, Kaeku Lee, and Jane Junn. 2011. Asian American Political Participation. New York: Russell Sage Foundation.

Yellow Horse, Aggie J., Karen Kuo, Eleanor K. Seaton, and Edward D. Vargas. 2021. Asian Americans' Indifference to Black Lives Matter: The Role of Nativity, Belonging and Acknowledgment of Anti-Black Racism. Social Sciences 10: 168. [CrossRef]

Zheng, Bang Quan. 2019. The Patterns of Asian Americans' Partisan Choice: Policy Preferences and Racial Consciousness. Social Science Quarterly 100: 1593-608. [CrossRef] 